\title{
Vibrational Investigation of Pressure-Induced Phase Transitions of Hydroxycarbonate Malachite $\mathrm{Cu}_{2}\left(\mathrm{CO}_{3}\right)(\mathrm{OH})_{2}$
}

\author{
Jing Gao ${ }^{1, *}$ and Xueyin Yuan ${ }^{2, *(D)}$ \\ 1 State Key Laboratory of Lithospheric Evolution, and Institutions of Earth Science, Institute of Geology \\ and Geophysics, Chinese Academy of Sciences, Beijing 100029, China \\ 2 MNR Key Laboratory of Metallogeny and Mineral Assessment, Institute of Mineral Resources, \\ Chinese Academy of Geological Sciences, Beijing 100037, China \\ * Correspondence: gaojing@mail.iggcas.ac.cn (J.G.); xueyinyuan@outlook.com (X.Y.)
}

Received: 11 February 2020; Accepted: 17 March 2020; Published: 19 March 2020

\begin{abstract}
Malachite $\mathrm{Cu}_{2}\left(\mathrm{CO}_{3}\right)(\mathrm{OH})_{2}$ is a common hydroxycarbonate that contains about 15.3 wt \% $\mathrm{H}_{2} \mathrm{O}$. Its structural chemistry sheds light on other hydroxyl minerals that play a role in the water recycling of our planet. Here using Raman and infrared spectroscopy measurements, we studied the vibrational characteristics and structural evolution of malachite in a diamond anvil cell at room temperature $\left(25^{\circ} \mathrm{C}\right)$ up to $\sim 29 \mathrm{GPa}$. Three types of vibrations were analyzed including $\mathrm{Cu}-\mathrm{O}$ vibrations (300-600 $\left.\mathrm{cm}^{-1}\right),\left[\mathrm{CO}_{3}\right]^{2-}$ vibrations (700-1600 $\left.\mathrm{cm}^{-1}\right)$, and $\mathrm{O}-\mathrm{H}$ stretches $\left(3200-3500 \mathrm{~cm}^{-1}\right)$. We present novel observations of mode discontinuities at pressures of $\sim 7, \sim 15$, and $\sim 23 \mathrm{GPa}$, suggesting three phase transitions, respectively. First, pressure has a great effect on the degree of deformation of the $\left[\mathrm{CuO}_{6}\right]$ octahedron, as is manifested by the various shifting slopes of the $\mathrm{Cu}-\mathrm{O}$ modes. $\left[\mathrm{CuO}_{6}\right]$ deformation results in a rotation of the structural unit and accordingly a phase transition at $\sim 7 \mathrm{GPa}$. Upon compression to $15 \mathrm{GPa}$, the $\mathrm{O}-\mathrm{H}$ bands redshift progressively with significant broadness, indicative of an enhancement of the hydrogen bonding, a shortening of the $\mathrm{O}$... O distance, and possibly somewhat of a desymmetrization of the $\mathrm{O}-\mathrm{H} \cdots \mathrm{O}$ bond. $\mathrm{O}-\mathrm{H}$ mode hardening is identified above 15 GPa coupled with a growth in the amplitude of the lower-energy bands. These observations can be interpreted as some reorientation or reordering of the hydrogen bonding. A further increment of pressure leads to a change in the overall compression mechanism of the structure at $23 \mathrm{GPa}$, which is characterized by the blueshift of the $\mathrm{O}-\mathrm{H}$ stretches and the softening of the $\mathrm{O}-\mathrm{C}-\mathrm{O}$ in-plane bending bands. The hydrogen bonding weakens due to a substantial enhancement of the $\mathrm{Cu}-\mathrm{H}$ repulsion effect, and the $\mathrm{O} \cdots \mathrm{O}$ bond length shows no further shortening. In addition, the change in the local geometry of hydrogen is also induced by the softening of the $\left[\mathrm{CO}_{3}\right]^{2-}$ units. In this regard we may expect malachite and other analogous hydroxyl minerals as capable of transporting water downward towards the Earth's transition zone ( 23 GPa). Our results furnish our knowledge on the chemistry of hydrogen bonding at mantle conditions and open a new window in understanding the synergistic relations of water and carbon recycling in the deep Earth.
\end{abstract}

Keywords: hydroxycarbonate; hydrogen bonding; phase transition; diamond anvil cell

\section{Introduction}

The circulation of water plays an important role in geological processes in the evolution of our planet. In descending slabs, the crustal water is recycled into the Earth's mantle through hydrogen-bearing phases (e.g., serpentine $\left.\mathrm{Mg}_{3}\left(\mathrm{Si}_{4} \mathrm{O}_{10}\right)(\mathrm{OH})_{2}\right)$ and nominally anhydrous minerals (e.g., olivine $\left.(\mathrm{Mg}, \mathrm{Fe})_{2}(\mathrm{SiO} 4)\right)$ [1]. At various depths in subduction regions, the presence of water is probably the origin of the observed seismic anomalies such as low velocities and high shear wave 
splitting [2]. Meanwhile, slabs dehydrating progressively with depth and releasing water provide a potential mechanism for rehydration of the overlaying mantle, exerting profound influence on mantle convection and the resulting volatile recycling and heterogeneity $[1,3]$. Thus, for insights into water recycling into the Earth's interior, as well as its effects on the physicochemical conditions and dynamics of the mantle, a primary method is to study the thermodynamic stabilities of hydrogen-bearing minerals under high pressure conditions.

A succession of dense hydrous magnesium silicates (e.g., phase $\mathrm{B}$ : $\mathrm{Mg}_{10} \mathrm{Si}_{3} \mathrm{O}_{14}(\mathrm{OH})_{4}$, phase D: $\mathrm{MgSi}_{2} \mathrm{O}_{4}(\mathrm{OH})_{2}$, phase $\mathrm{E}: \mathrm{Mg}_{2} \mathrm{SiO}_{2}(\mathrm{OH})_{4}$, phase $\mathrm{H}: \mathrm{MgSiO}_{2}(\mathrm{OH})_{2}$ and super-hydrous phase $\mathrm{B}$ ) has been demonstrated as stable within the subducting lithosphere to lower mantle pressures [4-7]. Yet these $\mathrm{Mg}$ end-members decompose at temperatures lower than those of the mantle geotherms, and thus they cannot be long-term water reservoirs in the deep Earth. Substitution of Mg with Al stabilizes the hydrous phases to higher temperatures [8-10], but their occurrences have been scarcely reported in nature. A pressing issue emerges regarding whether other hydrogen-bearing phases exist that could account for the estimated water content inside the Earth [11-13].

Here we focus on a hydroxycarbonate malachite $\mathrm{Cu}_{2}\left(\mathrm{CO}_{3}\right)(\mathrm{OH})_{2}$ which contains about $15.3 \mathrm{wt}$ $\% \mathrm{H}_{2} \mathrm{O}$. Malachite is an important index mineral for hydrous environments enriched with carbonate ions [14], which provide crucial clues for sequestration and circulation of water on the Earth. Malachite has a relatively simple chemistry whose high-pressure behavior will increase our understanding of the hydrogen-carriers in the deep Earth. Malachite also merits our preferential considerations because of its superior bonding of hydrogen with $\left[\mathrm{CuO}_{6}\right]$ octahedron due to the strong and partially covalent effect of $\mathrm{Cu}^{2+}[15,16]$. At atmospheric pressure, the thermodynamic properties of malachite have been studied in terms of heat capacity and enthalpy change in the temperature range of $20-500{ }^{\circ} \mathrm{C}$ [17]. Above $380^{\circ} \mathrm{C}$ malachite breaks down releasing water and $\mathrm{CO}_{2}$ simultaneously [18]. The application of pressure, however, counteracts the thermal decomposition effect, shifts the thermodynamic stability toward higher temperatures, and even realizes an over-hydrated state for some hydrous minerals (e.g., zeolites; [19]); but the effect of pressure on the properties of malachite is confused considerably. Measurements on the behaviors of malachite under pressure have been confined to an X-ray diffraction study under $10 \mathrm{GPa}$ [20] and a density functional theory research to a maximum pressure of $5.72 \mathrm{GPa}$ [21]. It has been reported that a phase transition of malachite occurs at 6-7 GPa driven by a deformation effect of $\left[\mathrm{CuO}_{6}\right]$ octahedron. The higher-pressure phase, rosasite, is much higher in density and atomic interactions are dramatically enhanced. The behavior of hydrogen during structural change is more crucial in water preservation, yet it is the least understood. Therefore, the present study takes advantage of in-situ Raman and infrared spectroscopy to examine the vibrational characteristics of malachite with contributions from all types of modes. With the aim of revealing the physical processes involving the response of hydrogen to pressure, the synergistic relations of hydrogen and the coordinated $\left[\mathrm{CuO}_{6}\right]$ octahedron and $\left[\mathrm{CO}_{3}\right]^{2-}$ units are discussed in detail at the molecular level. Our results will add to our knowledge of the structural chemistry of hydrogen agents in the deep Earth.

\section{Samples and Experiments}

The malachite sample used for the high-pressure experiments was picked out from botryoidal aggregates collected at Yangchun copper mine in Yangchun, Guangdong, China. Its composition formula has been determined as $\left(\mathrm{Cu}_{1.92} \mathrm{Fe}_{0.06} \mathrm{Mn}_{0.02}\right)\left(\mathrm{CO}_{3}\right)(\mathrm{OH})_{2}$ (for simplicity written as $\mathrm{Cu}_{2}\left(\mathrm{CO}_{3}\right)(\mathrm{OH})_{2}$ in the following text) by an inductively coupled plasma optical emission spectrometer at the Institute of Tibetan Plateau Research, Chinese Academy of Sciences (ITPCAS), Beijing, China. The crystal structure, identified by X-ray diffraction ( $\mathrm{Cu}$ k radiation) at the ITPCAS, possesses a monoclinic symmetry (space group: $P 2_{1} / a$, $Z=4)$. The values of the lattice constants are derived as $a_{0}=9.488(2) \AA, b_{0}=11.955(2) \AA, c_{0}=3.247(2)$ $\AA, \beta=98.62(2)^{\circ}$, and $V=364.6 \AA^{3}$, in agreement with $a_{0}=9.502 \AA, b_{0}=11.974 \AA, c_{0}=3.24 \AA, \beta=98.75^{\circ}$, and $V=364.35 \AA^{3}$ in [16].

A symmetrical-type diamond anvil cell [22] with type-II diamond anvils (culet size $300 \mu \mathrm{m}$ ) was utilized for generating pressure. A rhenium gasket with an initial thickness of $250 \mu \mathrm{m}$, was pre-indented 
to $50 \mu \mathrm{m}$. A hole of $150 \mu \mathrm{m}$ in diameter was drilled in the center of the indentation by electro-spark erosion, used as a sample chamber. A malachite chip was loaded into the chamber filled with silicone oil as a pressure transmitting medium in Raman spectroscopic measurements. For infrared spectroscopy, a thin malachite chip $10 \mu \mathrm{m}$ in thickness was sandwiched between dried $\mathrm{KBr}$ layers that served as an infrared window and pressure medium. Pressures were measured according to the shifts of ruby fluorescence lines [23]. Both vibrational measurements were conducted at the Institute of Geology and Geophysics, Chinese Academy of Sciences (IGGCAS), Beijing, China.

In Raman spectroscopy experiments, a $488 \mathrm{~nm}$ solid-state continuous-wave laser equipped with WITec alpha 300R was employed as an excitation source. A piece of single-crystal silicon was used to calibrate the wave numbers of the Raman shifts. The spectra of malachite were recorded through a $10 \times$ magnification objective lens with a 0.55 numerical aperture in backscattering geometry to the sample. After scattered Raman light passed through a pinhole of $20 \mu \mathrm{m}$, the light was dispersed on a grating of $300 \mathrm{~g} / \mathrm{mm}$, resulting in a spectral resolution of $1.105 \mathrm{~cm}^{-1}$ in the spectral region of $0-4500 \mathrm{~cm}^{-1}$. The laser power was $20 \mathrm{~mW}$ and the acquisition time for each spectrum was $10 \mathrm{~s}$ with an accumulation of two times.

Infrared spectroscopy is particularly sensitive to rearrangements of hydrogen atoms in structures. High-pressure Fourier transform infrared spectroscopy (FTIR) measurements were carried out on a Bruker VERTEX 70V instrument (Bruker Optik GmbH, Ettlingen, Germany). A Bruker Hyperion 2000 microscope (Bruker Optics, Billerica, MA, USA) was used to record spectra in a $20 \times 20 \mu \mathrm{m}^{2}$ aperture in a region of $650-5000 \mathrm{~cm}^{-1}$, encompassing the vibrational characteristics of both $\mathrm{O}-\mathrm{H}$ stretches and $\left[\mathrm{CO}_{3}\right]^{2-}$ modes. A KBr beam-splitter (Interspectrum, Tartumaa, Estonia) and a liquid-nitrogen cooled MCT-A (mercury-cadmium-telluride) detector (Block Engineering Technology, Southborough, MA, USA) were applied. A total of 640 scans were accumulated in each spectrum, and the acquisition time for each spectrum was $520 \mathrm{~s}$, to improve the signal-to-noise ratio at a $4 \mathrm{~cm}^{-1}$ resolution. For individual pressure increments, we recorded a background spectrum and automatically subtracted it from the pattern of the sample.

When collecting a spectrum with new features under pressure, we check the spectra of different positions to verify if the anomalies are general characteristics that are indicative of structural changes or just due to local stress or defects. After competition of the experiments, the spectral manipulation and analyses were undertaken by Jandel Peakfit software package (v4.12, Systat Software, San Jose, CA, USA). A Voight function was used for peak fitting with the minimum components used. The fitting was performed until reproducible results were obtained with squared correlations $R^{2} \geq 0.995$.

\section{Results}

\subsection{Vibrational Characteristics of Malachite at Atmospheric Pressure and Room Temperature}

A representative Raman spectrum of malachite at atmospheric pressure and room temperature $\left(25^{\circ} \mathrm{C}\right)$ is presented in Figure 1 . The spectrum is divided into three sections depending on the type of vibration. In the spectral region of $100-600 \mathrm{~cm}^{-1}$, there is a set of sharp modes, with most intensity at $152.82,177.63,219.82,270.15,332.21,352.68,511.10$, and $533.12 \mathrm{~cm}^{-1}$. These bands are predicted to be produced by external vibrations between $\mathrm{Cu}^{2+}$ and the connected $\left[\mathrm{CO}_{3}\right]^{2-} /[\mathrm{OH}]^{-}$units (essentially at $\sim 300-600 \mathrm{~cm}^{-1}$ ) and the librational bands of the $\left[\mathrm{CO}_{3}\right]^{2-}$ units (below $300 \mathrm{~cm}^{-1}$ ) [15]. Raman modes occurring in the frequency range of $700-1600 \mathrm{~cm}^{-1}$ are due to the $\left[\mathrm{CO}_{3}\right]^{2-}$ internal modes. The two bands, 1065.82 and $1092.54 \mathrm{~cm}^{-1}$, correspond to the symmetrical stretching vibrations $\left(v_{1}\right)$. The in-plane bending $\left(v_{4}\right)$ splits into two components at 719.12 and $754.68 \mathrm{~cm}^{-1}$ because of the lowered site group symmetry surrounding the $\left[\mathrm{CO}_{3}\right]^{2-}$ units. Another splitting mode is the asymmetrical stretches $\left(v_{3}\right)$ which show two separated bands at 1367.92 and $1494.95 \mathrm{~cm}^{-1}$. The Raman spectrum for the $\mathrm{O}-\mathrm{H}$ stretching region is dominated by two broad peaks centered at 3321.92 and $3381.77 \mathrm{~cm}^{-1}$, indicating that the hydrogen sites are not equivalent. These assignments are referred to from previous studies [15,24-27]. 


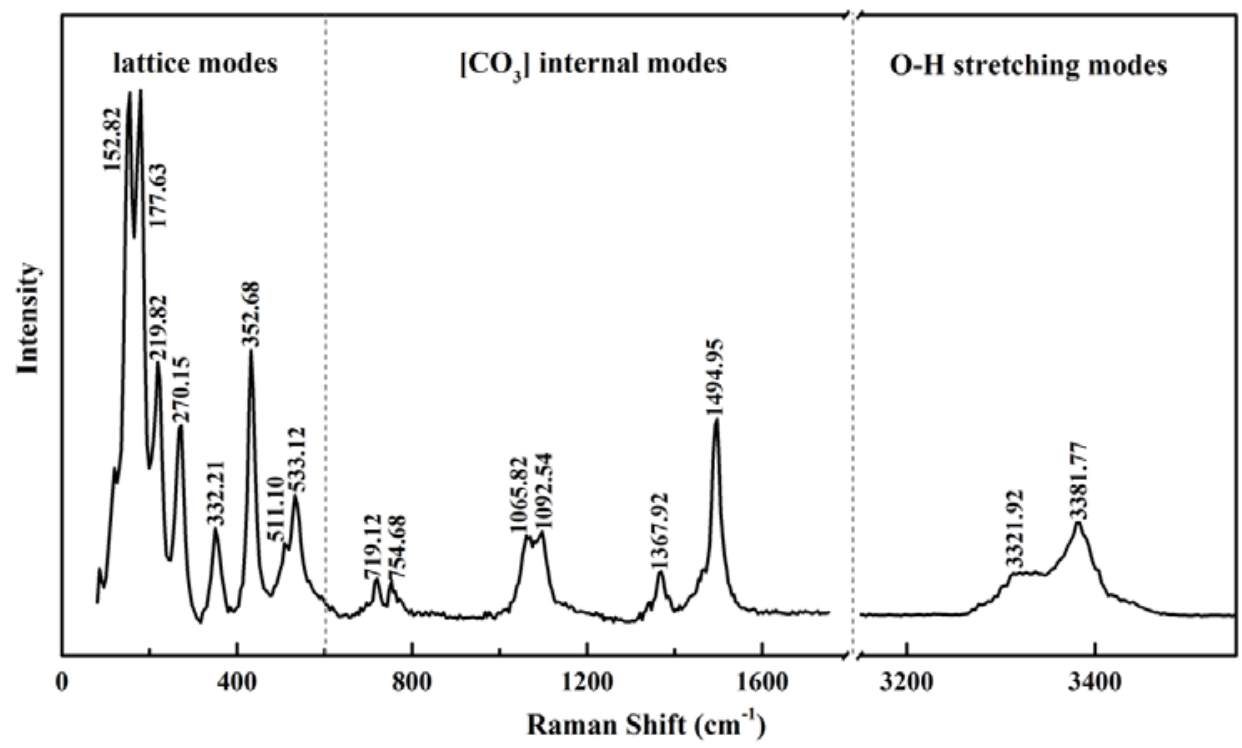

Figure 1. Raman spectrum of malachite at atmospheric pressure; three sections depending on types of vibration are noted with the same scale. The standard deviation in the digit of the peak position is 0.01 .

The infrared spectrum of malachite encompasses the $\left[\mathrm{CO}_{3}\right]^{2-}$ internal modes and $\mathrm{O}-\mathrm{H}$ stretches (Figure 2). In common with the Raman spectrum, the $\mathrm{O}-\mathrm{C}-\mathrm{O}$ symmetrical vibration is resolved by two peaks, a progressive one at 1097.22 and a weak companion at $1117.96 \mathrm{~cm}^{-1}$; the in-plane mode splits at 711.54 and $747.58 \mathrm{~cm}^{-1}$, but the asymmetrical stretches are characterized with two broad bands over 1250-1600 $\mathrm{cm}^{-1}$ spectral range which is best deconvoluted as five components. Infrared modes at $815.92,828.10$, and $876.28 \mathrm{~cm}^{-1}$ are derived from the out-of-plane bending ( $v_{2}$, Raman spectra suffer a lack of signal). There is a mixed band at $\sim 1043.4 \mathrm{~cm}^{-1}$ related to the in-plane and out-of-plane $\mathrm{Cu}-\mathrm{OH}$ bending. The two $\mathrm{O}-\mathrm{H}$ stretching peaks are observed with the most absorbance at 3334.72 and $3408.95 \mathrm{~cm}^{-1}$. Despite the intensity of hydrogen bonding, it is not expected to affect the vibrations of the $\left[\mathrm{CO}_{3}\right]^{2-}$ units significantly as the $\mathrm{O}-\mathrm{C}-\mathrm{O}$ bands remain sharp and do not shift much with respect to those in carbonates. Infrared weak modes located in the frequency range of $2850-3000 \mathrm{~cm}^{-1}$ are due to the $\mathrm{C}-\mathrm{H}$ stretching vibrations from the silicone oil (pressure medium). The above assignments and interpretations are in agreement with those in previous studies [28,29].

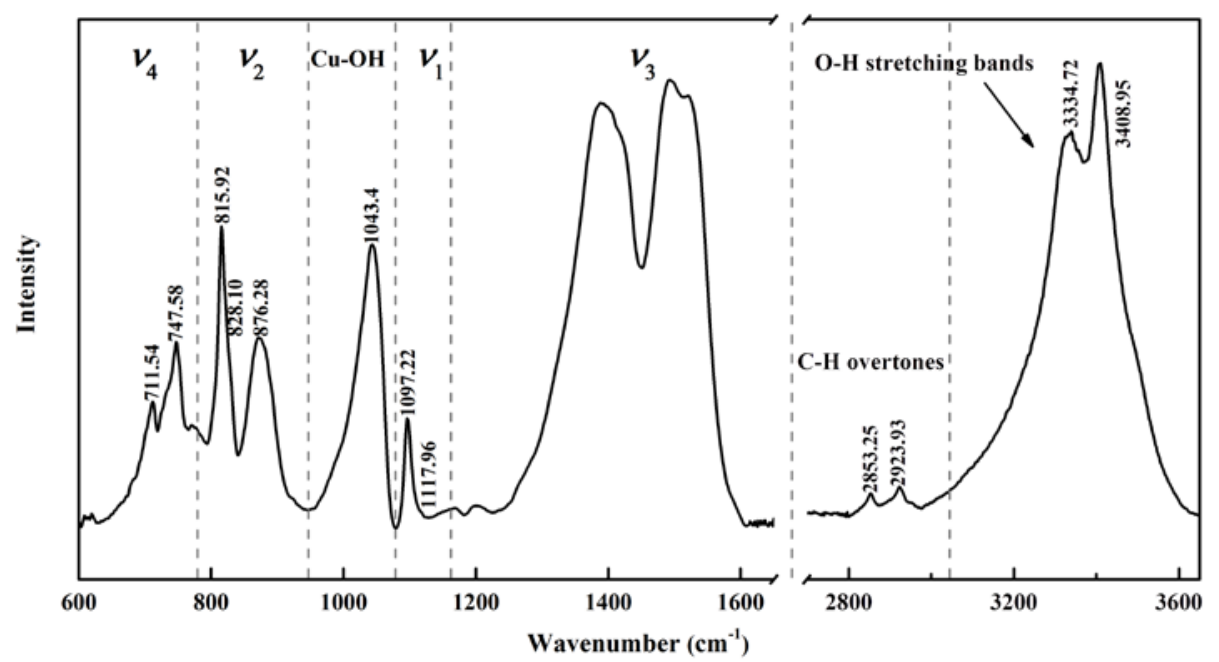

Figure 2. Infrared spectrum of malachite at atmospheric pressure and room temperature with vibrations noted. 


\subsection{Vibrational Changes of Malachite under Pressure}

Malachite was compressed at room temperature up to 28.9 and $29.2 \mathrm{GPa}$, respectively, in Raman and infrared spectroscopic measurements, and monitored on both compression and decompression processes. Selected spectra at elevated pressures are displayed in Figures 3 and 4 . In addition to the modes observed at atmospheric pressure, two more bands appear in the Raman spectra in the range of $2850-3000 \mathrm{~cm}^{-1}$ which are assignable to the $\mathrm{C}-\mathrm{H}$ stretches of the pressure medium. In additin, more $\mathrm{O}-\mathrm{H}$ stretching bands are resolved in the infrared spectra due to the high sensitivity of hydrogen bonding to pressure. Mode frequencies derived from the high-pressure Raman and infrared data are listed in Tables 1 and 2. We selected $\mathrm{Cu}-\mathrm{O}$ bands and $\mathrm{O}-\mathrm{C}-\mathrm{O}$ stretches from the Raman data for pressure effect analyses, while the modes representative of $\mathrm{O}-\mathrm{C}-\mathrm{O}$ bending and $\mathrm{O}-\mathrm{H}$ stretches are measured from the infrared spectra. The change in frequency for the selected modes as a function of pressure are plotted in Figure 5 with the fitting results are listed in Table 3.

Three dramatic changes in the vibrational spectra of malachite are evident as pressure grows to $\sim 7, \sim 15$, and $\sim 23 \mathrm{GPa}$. First, upon compression to $\sim 7 \mathrm{GPa}$, the $\mathrm{Cu}-\mathrm{O}$ modes in the lower-energy range of 300-400 $\mathrm{cm}^{-1}$ redshift whereas the higher-energy $\left(400-600 \mathrm{~cm}^{-1}\right)$ blueshift with a more pronounced pressure dependence $\left(d_{v i} / d_{P}\right)_{T}$ (vi is the frequency of a mode under a certain pressure and $P$ is pressure; $\left(d_{v i} / d_{P}\right)_{T}$ means the slope of mode shifting with pressure at room temperature). This observation suggests an increasing degree of the deformation of the $\left[\mathrm{CuO}_{6}\right]$ octahedron. It is noted that the pressure-induced redshift of the lower-energy modes provides a clue to the instability of malachite under higher pressure. Thus, at $\sim 7 \mathrm{GPa}$, the band initially at $354.56 \mathrm{~cm}^{-1}(0.6 \mathrm{GPa})$ splits into 347.80 and $358.99 \mathrm{~cm}^{-1}$ (Figure 5a). In addition, a sharp increase of $\Delta v=10.5 \mathrm{~cm}^{-1}$ occurs in the frequency of an $\mathrm{O}-\mathrm{C}-\mathrm{O}$ in-plane band $710.17 \mathrm{~cm}^{-1}(0.8 \mathrm{GPa})$ at $\sim 7 \mathrm{GPa}$ coupled with a change in the pressure dependence from $0.56(8) \mathrm{cm}^{-1} \cdot \mathrm{GPa}^{-1}$ to $-1.48(4) \mathrm{cm}^{-1} \cdot \mathrm{GPa}^{-1}$. An out-of-bending band $891.52 \mathrm{~cm}^{-1}$ first redshifts at a slope of $-3.60(4) \mathrm{cm}^{-1} \cdot \mathrm{GPa}^{-1}$, but across $\sim 7 \mathrm{GPa}$ it turns to blueshift with pressure at $0.92(8) \mathrm{cm}^{-1} \cdot \mathrm{GPa}^{-1}$ (Figure $5 \mathrm{c}$ ). These anomalies are indicative of the onset of a phase transition. The transition pressure determined here is consistent with the results in previous studies $[20,21]$. As pressure grows to $\sim 7 \mathrm{GPa}$, the $\left[\mathrm{CO}_{3}\right]^{2-}$ stretches shift to higher frequencies at a constant slope of $2.12(3) \mathrm{cm}^{-1} \cdot \mathrm{GPa}^{-1}$ for the symmetrical modes and $\sim 3.5 \mathrm{~cm}^{-1} \cdot \mathrm{GPa}^{-1}$ for the asymmetrical (Figure $5 \mathrm{~b}$ ); the pressure slopes of the $\mathrm{O}-\mathrm{C}-\mathrm{O}$ stretches in malachite are comparable to those in carbonates [30-33]. The rest of the bending bands $829.03,818.26$, and $749.42 \mathrm{~cm}^{-1}$ display negligible pressure dependence. Our observation of the marginal pressure shifts for the $\mathrm{O}-\mathrm{C}-\mathrm{O}$ bending in malachite is a characteristic in carbonates $\left(\mathrm{MCO}_{3}, \mathrm{M}=\mathrm{Ca}, \mathrm{Cd}, \mathrm{Mn}, \mathrm{Fe}, \mathrm{Zn}, \mathrm{Mg}\right.$, etc.) [30-34]. This bending (and the force constant) involves $\mathrm{O}^{2-}$ deviation at an oblique angle to the $\mathrm{M}-\mathrm{O}$ bond, thus their frequencies are anticipated to be insensitive to the changes in the $\mathrm{M}-\mathrm{O}$ bond strength. We also note that the band $891.52 \mathrm{~cm}^{-1}$ exhibits sizeable broadening with respect to the rest bending under pressure.

More marked mode shifting is observed in the $\mathrm{O}-\mathrm{H}$ stretching region where all the vibrations redshift (Figure $5 \mathrm{~d}$ ), the pressure dependence varying from $-10.72(6) \mathrm{cm}^{-1} \cdot \mathrm{GPa}^{-1}$ to $-5.54(1)$ $\mathrm{cm}^{-1} \cdot \mathrm{GPa}^{-1}$. Our results on the $\mathrm{O}-\mathrm{H}$ stretches shifting in malachite coincide with those in other hydrogen-bearing minerals [35]. At $\sim 7 \mathrm{GPa}$, discontinuities are monitored in the pressure-frequency slopes; the pressure dependence of the band $3485.88 \mathrm{~cm}^{-1}(0.8 \mathrm{GPa})$ decreases from $-7.52(9) \mathrm{cm}^{-1} \cdot \mathrm{GPa}^{-1}$ to $-3.51(3) \mathrm{cm}^{-1} \cdot \mathrm{GPa}^{-1}$, whereas the other two 3410.79 and $3251.55 \mathrm{~cm}^{-1}$ increase from $-5.54(1)$ $\mathrm{cm}^{-1} \cdot \mathrm{GPa}^{-1}$ to $-8.13(2) \mathrm{cm}^{-1} \cdot \mathrm{GPa}^{-1}$ and $-10.72(6) \mathrm{cm}^{-1} \cdot \mathrm{GPa}^{-1}$ to $-12.58(4) \mathrm{cm}^{-1} \cdot \mathrm{GPa}^{-1}$, respectively. Simultaneously, a steep decrease of $\Delta v=\sim 48 \mathrm{~cm}^{-1}$ occurs in the frequency of the band $3410.79 \mathrm{~cm}^{-1}$ over the 5.1-7 GPa pressure span and a new band around $950 \mathrm{~cm}^{-1}$ develops which is assignable to the $\mathrm{O}-\mathrm{H}$ out-of-bending $[25,36]$. In this process significant broadness is observed for all $\mathrm{O}-\mathrm{H}$ stretches. 


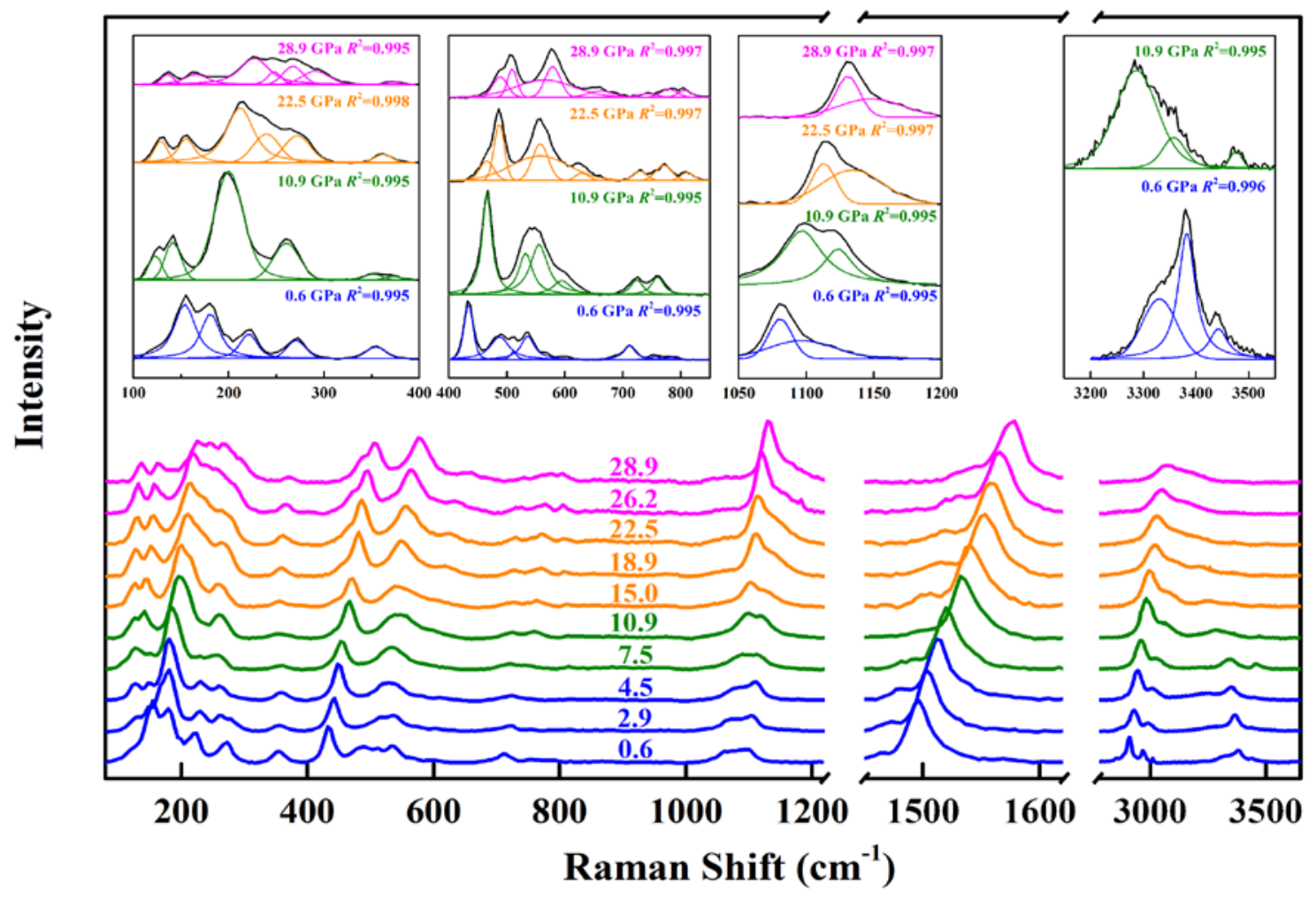

Figure 3. Raman spectra of $\mathrm{Cu}_{2}\left(\mathrm{CO}_{3}\right)(\mathrm{OH})_{2}$ at elevated pressures. The insertions are the zoom-in views of the peak fitting results, which are indicative of phase transitions.

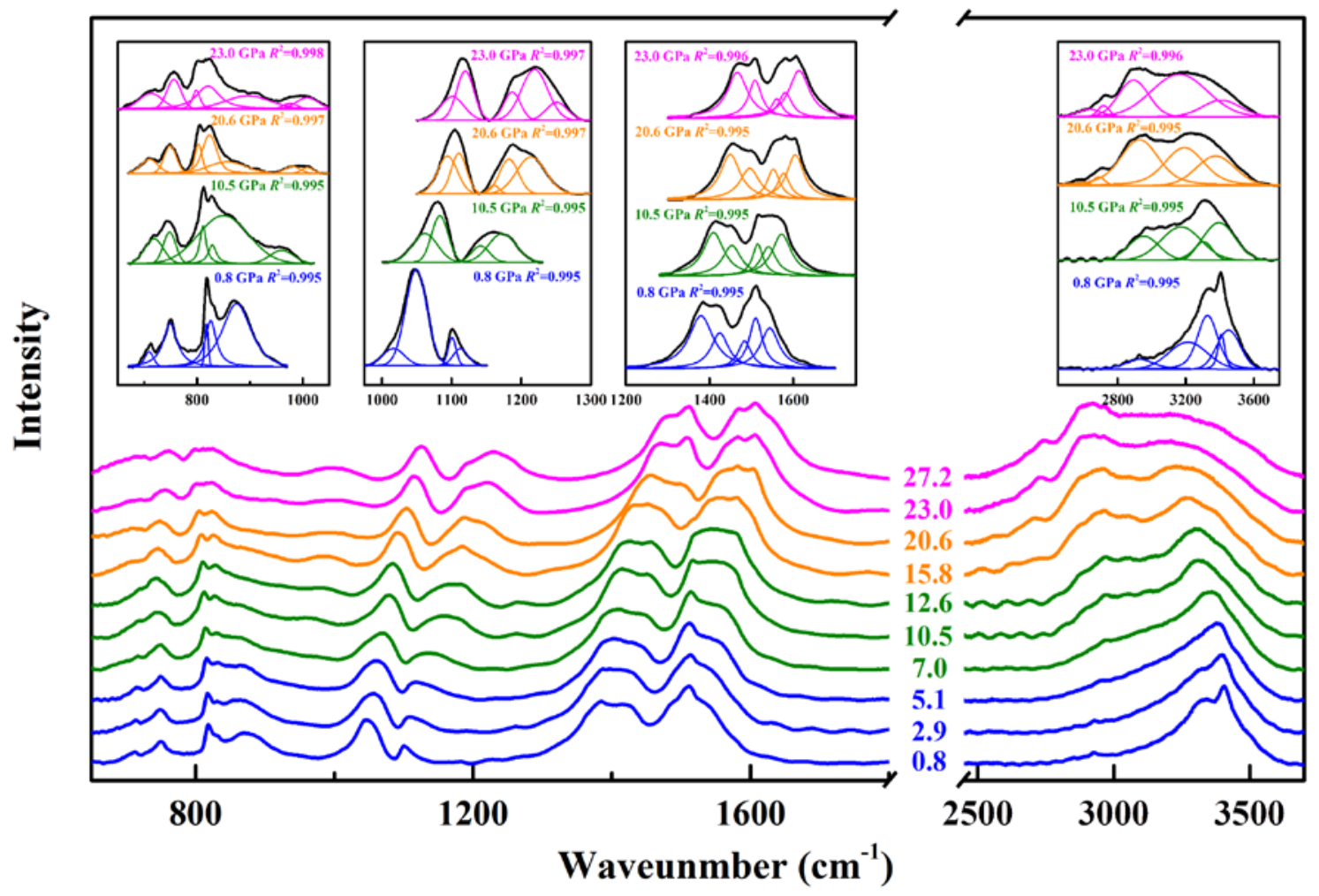

Figure 4. Infrared spectra of $\mathrm{Cu}_{2}\left(\mathrm{CO}_{3}\right)(\mathrm{OH})_{2}$ with increasing pressure.

At $\sim 15 \mathrm{GPa}$, we notice a merging of double peaks at $\sim 370 \mathrm{~cm}^{-1}$, a mode split at $\sim 1000 \mathrm{~cm}^{-1}$, and dramatic changes in the mode intensities of all types. These changes are along with the development of bands at $\sim 250, \sim 450, \sim 800, \sim 1150, \sim 1480$, and $\sim 2800 \mathrm{~cm}^{-1}$. Further compression enhances the 
bands $\sim 450$ and $\sim 1150 \mathrm{~cm}^{-1}$, which is suggestive of an increase in the additional $\mathrm{Cu}-\mathrm{O}$ interactions. The systematical redshifting of the lower-energy $\mathrm{Cu}-\mathrm{O}$ modes slow down and display zero pressure slope above $\sim 15 \mathrm{GPa}$, yet the higher-energy modes blueshift as usual (Figure $5 \mathrm{a}$ ). The two bands correspond to the $\left[\mathrm{CO}_{3}\right]^{2-}$ internal modes, one at $\sim 800 \mathrm{~cm}^{-1}$ increases in amplitude and the other at $\sim 1480 \mathrm{~cm}^{-1}$ remains at a similar amplitude under pressure. The most striking change is the mode hardening of the $\mathrm{O}-\mathrm{H}$ stretches; for example, the band $3251.55 \mathrm{~cm}^{-1}$ redshifts sharply from $-12.58(4)$ $\mathrm{cm}^{-1} \cdot \mathrm{GPa}^{-1}$ to $-1.03(2) \mathrm{cm}^{-1} \cdot \mathrm{GPa}^{-1}$ (Figure $5 \mathrm{~d}$ ). The comparatively weaker pressure slope is also observed in the shift of the band appearing at $\sim 950 \mathrm{~cm}^{-1}$ at $\sim 7 \mathrm{GPa}$, which confirms that this band contains a contribution from the $\mathrm{O}-\mathrm{H}$ vibrations. As pressure increases, the two higher-energy bands 3485.88 and $3410.79 \mathrm{~cm}^{-1}$ give rise to a lower-energy band $3251.55 \mathrm{~cm}^{-1}$, the latter becoming prominent above $\sim 15 \mathrm{GPa}$. A new band emerges at $\sim 2800 \mathrm{~cm}^{-1}$.

As pressure further increases to $\sim 23 \mathrm{GPa}$, the $\mathrm{O}-\mathrm{C}-\mathrm{O}$ stretching modes go on blueshift but with smaller pressure slopes (Figure $5 \mathrm{~b}$ ). The slope reduces from $2.12(3) \mathrm{cm}^{-1} \cdot \mathrm{GPa}^{-1}$ to $1.69(6) \mathrm{cm}^{-1} \cdot \mathrm{GPa}^{-1}$ and $1.38(8)$ $\mathrm{cm}^{-1} \cdot \mathrm{GPa}^{-1}$ for the two symmetrical modes, respectively, and from $\sim 2.2 \mathrm{~cm}^{-1} \cdot \mathrm{GPa}^{-1}$ to $\sim 1.6 \mathrm{~cm}^{-1} \cdot \mathrm{GPa}^{-1}$ for the asymmetrical band $1484.29 \mathrm{~cm}^{-1}(0.8 \mathrm{GPa})$; the other asymmetrical band emerging at $\sim 15 \mathrm{GPa}$ at $\sim 1480 \mathrm{~cm}^{-1}$ preserves a constant slope of $2.39(3) \mathrm{cm}^{-1} \cdot \mathrm{GPa}^{-1}$. The out-of-bending bands maintain a negligible pressure dependence as before, but the in-plane bands speed up dramatically. Specifically, the band $749.42 \mathrm{~cm}^{-1}$ accelerates from $0.13(2) \mathrm{cm}^{-1} \cdot \mathrm{GPa}^{-1}$ to $2.25(7) \mathrm{cm}^{-1} \cdot \mathrm{GPa}^{-1}$ and the other $749.42 \mathrm{~cm}^{-1}$ turns around from $-1.48(4) \mathrm{cm}^{-1} \cdot \mathrm{GPa}^{-1}$ to $2.40(5) \mathrm{cm}^{-1} \cdot \mathrm{GPa}^{-1}$ (Figure $5 \mathrm{c}$ ). In addition, a further decrease of $\Delta v=\sim 66 \mathrm{~cm}^{-1}$ is observed in the frequency of the $\mathrm{O}-\mathrm{H}$ band $3410.79 \mathrm{~cm}^{-1}$ over the 20.6-23 GPa span, followed by a rapid reduction in the amplitude (Figure $5 \mathrm{~d}$ ). The other two bands 3485.88 and $3251.55 \mathrm{~cm}^{-1}$, contrary to the redshift nature, begin blueshift trends at $23 \mathrm{GPa}$. In this process, no appreciable broadness of the $\mathrm{O}-\mathrm{H}$ modes is observed.

Table 1. Selected Raman mode frequencies $\left(\mathrm{cm}^{-1}\right)$ of $\mathrm{Cu}_{2}\left(\mathrm{CO}_{3}\right)(\mathrm{OH})_{2}$ at various pressures.

\begin{tabular}{|c|c|c|c|c|c|c|c|c|}
\hline \multirow{2}{*}{$\begin{array}{c}\boldsymbol{P}(\mathrm{GPa}) \\
0.6\end{array}$} & \multicolumn{4}{|c|}{ External Modes } & \multicolumn{2}{|c|}{$\mathrm{O}-\mathrm{C}-\mathrm{O} v_{1}$} & \multicolumn{2}{|c|}{$\mathrm{O}-\mathrm{C}-\mathrm{O} v_{3}$} \\
\hline & & 354.56 & & 433.56 & 1069.50 & 1099.28 & 1496.66 & \\
\hline 1.7 & & 355.09 & & 437.95 & 1071.38 & 1100.94 & 1500.27 & \\
\hline 2.9 & & 355.91 & & 441.62 & 1073.93 & 1105.19 & 1504.72 & \\
\hline 4.5 & & 358.75 & & 446.55 & 1079.33 & 1109.41 & 1513.64 & \\
\hline 7.5 & 347.80 & 358.99 & & 453.90 & 1086.83 & 1115.00 & 1521.14 & \\
\hline 9.5 & 350.52 & 370.21 & & 457.65 & 1090.27 & 1118.80 & 1527.12 & \\
\hline 10.9 & 353.64 & 373.91 & & 462.45 & 1094.03 & 1122.41 & 1532.52 & \\
\hline 15.0 & 368.41 & & 449.79 & 471.24 & 1100.35 & 1129.64 & 1541.75 & 1501.10 \\
\hline 16.9 & 370.14 & & 452.75 & 474.92 & 1105.21 & 1133.88 & 1546.34 & 1506.03 \\
\hline 18.9 & 374.39 & & 457.62 & 480.92 & 1110.69 & 1139.89 & 1552.74 & 1511.19 \\
\hline 22.5 & 377.48 & & 464.41 & 486.29 & 1114.10 & 1145.50 & 1559.07 & 1518.74 \\
\hline 23.6 & 379.38 & & 468.64 & 490.66 & 1117.88 & 1149.70 & 1561.93 & 1521.73 \\
\hline 26.2 & 381.76 & & 473.72 & 495.23 & 1120.47 & 1154.93 & 1566.39 & 1527.64 \\
\hline 28.9 & 383.71 & & 480.19 & 500.75 & 1124.82 & 1158.14 & 1569.50 & 1534.45 \\
\hline 26.8 & & 386.69 & 485.05 & 505.92 & 1129.56 & 1162.06 & 1570.15 & 1533.91 \\
\hline 24.9 & & 384.44 & 478.48 & 498.02 & 1121.13 & 1152.00 & 1566.88 & 1529.47 \\
\hline 16.0 & & 372.40 & 458.21 & 479.98 & 1104.70 & 1134.86 & 1548.08 & 1505.95 \\
\hline 6.0 & & 356.88 & & 448.97 & 1082.56 & 1113.29 & 1519.00 & \\
\hline 0.9 & & 355.65 & & 435.62 & 1068.85 & 1100.42 & 1498.64 & \\
\hline
\end{tabular}

Note: The standard deviation in the digit is 0.01 . 
Table 2. Selected infrared mode frequencies $\left(\mathrm{cm}^{-1}\right)$ of $\mathrm{Cu}_{2}\left(\mathrm{CO}_{3}\right)(\mathrm{OH})_{2}$ at various pressures.

\begin{tabular}{|c|c|c|c|c|c|c|c|c|c|c|}
\hline $\begin{array}{c}P \\
(\mathrm{GPa})\end{array}$ & \multicolumn{2}{|c|}{$\mathrm{O}-\mathrm{C}-\mathrm{O} v_{4}$} & \multicolumn{2}{|c|}{$\mathrm{O}-\mathrm{C}-\mathrm{O} v_{2}$} & \multicolumn{3}{|c|}{$\mathrm{Cu}-\mathrm{OH}$ Bending } & \multicolumn{3}{|c|}{$\mathrm{O}-\mathrm{C}-\mathrm{O} v_{1}$} \\
\hline 0.8 & 710.17 & 749.42 & 818.26 & 829.03 & 891.52 & 1039.82 & 1056.97 & 1100.39 & 1111.28 & \\
\hline 2.9 & 712.92 & 748.41 & 817.36 & 829.29 & 882.33 & 1046.21 & 1065.26 & 1107.36 & 1124.71 & \\
\hline 5.1 & 713.42 & 749.39 & 816.44 & 829.77 & 875.99 & 1049.82 & 1070.01 & 1111.64 & 1131.22 & \\
\hline 7.0 & 723.92 & 748.22 & 813.76 & 830.70 & 865.66 & 1054.37 & 1076.79 & 1124.79 & 1149.76 & \\
\hline 8.2 & 722.26 & 746.22 & 812.63 & 830.74 & 863.87 & 1057.79 & 1079.18 & 1131.01 & 1160.99 & \\
\hline 10.5 & 716.99 & 746.54 & 810.98 & 829.79 & 863.95 & 1062.25 & 1083.73 & 1142.73 & 1173.99 & \\
\hline 12.6 & 717.95 & 746.61 & 809.86 & 829.82 & 867.35 & 1070.32 & 1090.08 & 1150.55 & 1182.68 & \\
\hline 14.7 & 712.98 & 746.47 & 808.56 & 828.74 & 869.47 & 1076.35 & 1092.58 & 1153.96 & 1184.35 & \\
\hline 15.8 & 711.33 & 746.60 & 806.78 & 827.57 & 872.52 & 1083.36 & 1098.38 & 1159.50 & 1183.22 & 1206.96 \\
\hline 18.3 & 707.77 & 746.44 & 805.66 & 827.46 & 873.88 & 1086.35 & 1102.45 & 1159.57 & 1183.53 & 1210.16 \\
\hline 20.6 & 704.43 & 748.79 & 803.84 & 825.34 & 875.02 & 1096.77 & 1111.82 & 1164.97 & 1183.63 & 1213.12 \\
\hline 23.0 & 707.69 & 756.48 & 800.00 & 823.64 & 876.26 & 1105.94 & 1121.93 & 1167.55 & 1186.86 & 1215.88 \\
\hline 25.1 & 711.64 & 762.12 & 799.51 & 821.99 & 878.55 & 1109.41 & 1125.73 & 1170.96 & 1188.74 & 1217.97 \\
\hline 27.2 & 716.95 & 766.21 & 799.43 & 824.12 & 878.15 & 1118.28 & 1131.59 & 1173.50 & 1190.95 & 1219.78 \\
\hline 29.2 & 722.55 & 770.75 & 799.87 & 825.47 & 879.81 & 1123.93 & 1135.84 & 1176.57 & 1193.68 & 1221.79 \\
\hline 26.9 & 714.22 & 759.66 & 800.69 & 825.85 & 879.56 & 1118.24 & 1131.29 & 1173.96 & 1192.74 & 1221.59 \\
\hline 20.3 & 710.25 & 755.23 & 804.23 & 825.06 & 875.56 & 1098.10 & 1115.32 & 1168.50 & 1185.95 & 1212.56 \\
\hline 14.3 & 713.56 & 751.03 & 809.32 & 827.55 & 870.62 & 1079.43 & 1094.95 & 1156.57 & 1179.80 & \\
\hline 5.8 & 716.23 & 750.66 & 816.22 & 829.56 & 868.65 & 1056.38 & 1075.70 & 1124.97 & 1146.75 & \\
\hline 0.0001 & 709.66 & 749.32 & 818.92 & 827.20 & 891.36 & 1044.12 & 1058.73 & 1100.55 & 1110.08 & \\
\hline $\begin{array}{c}P \\
(\mathrm{GPa})\end{array}$ & \multicolumn{4}{|c|}{$\mathrm{O}-\mathrm{C}-\mathrm{O} v_{3}$} & \multicolumn{4}{|c|}{ O-H Stretches } & & \\
\hline 0.8 & 1384.52 & 1423.33 & 1484.29 & 1510.79 & 1544.45 & 3251.55 & 3410.79 & 3485.88 & & \\
\hline 2.9 & 1391.70 & 1427.24 & 1492.21 & 1514.55 & 1550.64 & 3231.31 & 3399.94 & 3477.70 & & \\
\hline 5.1 & 1407.78 & 1440.58 & 1509.61 & 1535.22 & 1564.79 & 3205.45 & 3387.13 & 3453.68 & & \\
\hline 7.0 & 1413.73 & 1447.89 & 1512.54 & 1538.38 & 1570.04 & 3173.99 & 3339.44 & 3429.39 & & \\
\hline 8.2 & 1415.83 & 1448.94 & 1512.94 & 1541.26 & 1571.82 & 3148.03 & 3325.98 & 3427.53 & & \\
\hline 10.5 & 1425.18 & 1456.82 & 1516.06 & 1543.60 & 1574.57 & 3128.78 & 3309.45 & 3421.65 & & \\
\hline 12.6 & 1428.83 & 1460.45 & 1519.62 & 1547.71 & 1579.84 & 3106.58 & 3292.62 & 3411.01 & & \\
\hline 14.7 & 1426.93 & 1460.86 & 1520.14 & 1550.95 & 1581.95 & 3069.74 & 3274.80 & 3402.42 & & \\
\hline 15.8 & 1442.91 & 1468.96 & 1526.70 & 1554.42 & 1587.96 & 3062.83 & 3260.33 & 3391.76 & & \\
\hline 18.3 & 1449.75 & 1473.62 & 1543.34 & 1579.11 & 1602.90 & 3042.73 & 3245.98 & 3386.89 & & \\
\hline 20.6 & 1454.14 & 1480.85 & 1547.90 & 1582.65 & 1605.90 & 3047.87 & 3237.83 & 3383.73 & & \\
\hline 23.0 & 1461.73 & 1499.70 & 1552.97 & 1587.07 & 1611.39 & 3051.26 & 3171.74 & 3361.45 & & \\
\hline 25.1 & 1483.70 & 1510.38 & 1572.76 & 1609.05 & 1636.17 & 3054.36 & 3159.19 & 3358.61 & & \\
\hline 27.2 & 1492.88 & 1511.71 & 1579.78 & 1609.45 & 1639.02 & & 3157.10 & 3364.77 & & \\
\hline 29.2 & 1504.24 & 1536.99 & 1582.26 & 1610.19 & 1643.81 & & 3154.02 & 3370.67 & & \\
\hline 26.9 & 1495.70 & 1515.07 & 1582.39 & 1610.05 & 1638.81 & & 3159.92 & 3366.19 & & \\
\hline 20.3 & 1458.88 & 1484.03 & 1552.76 & 1585.45 & 1620.50 & 3048.75 & 3187.10 & 3364.96 & & \\
\hline 14.3 & 1444.24 & 1468.23 & 1526.67 & 1555.19 & 1590.31 & 3057.87 & 3264.41 & 3389.67 & & \\
\hline 5.8 & 1416.65 & 1445.09 & 1511.61 & 1539.60 & 1569.15 & & 3334.45 & 3428.01 & & \\
\hline 0.0001 & 1382.23 & 1421.92 & 1484.97 & 1512.94 & 1542.54 & & 3393.86 & 3473.88 & & \\
\hline
\end{tabular}

The vibrational data upon decompression show negligible hysteresis. As seen in Figure $5 \mathrm{a}, \mathrm{b}$, the external $\mathrm{Cu}-\mathrm{O}$ modes and $\mathrm{O}-\mathrm{C}-\mathrm{O}$ stretching modes, shifting to higher frequencies under pressure, are located at a little higher frequencies under similar pressures upon decompression. The redshift $\mathrm{O}-\mathrm{H}$ stretching modes shift back to higher frequencies during decompression but with lower frequencies under comparable pressures (Figure $5 \mathrm{~d}$ ). When pressure is released completely, the spectra characteristics of the pure malachite are recovered. This indicates that the malachite structure experienced elastic deformations under compression. During the following decompression process, the modes show a slightly delayed response to pressure, which should be accounted for by the hysteresis. The hysteresis is due likely to the polycrystalline sample used here that develops microscopic or local stress at grain boundaries, leading to a slightly delayed relaxation. 

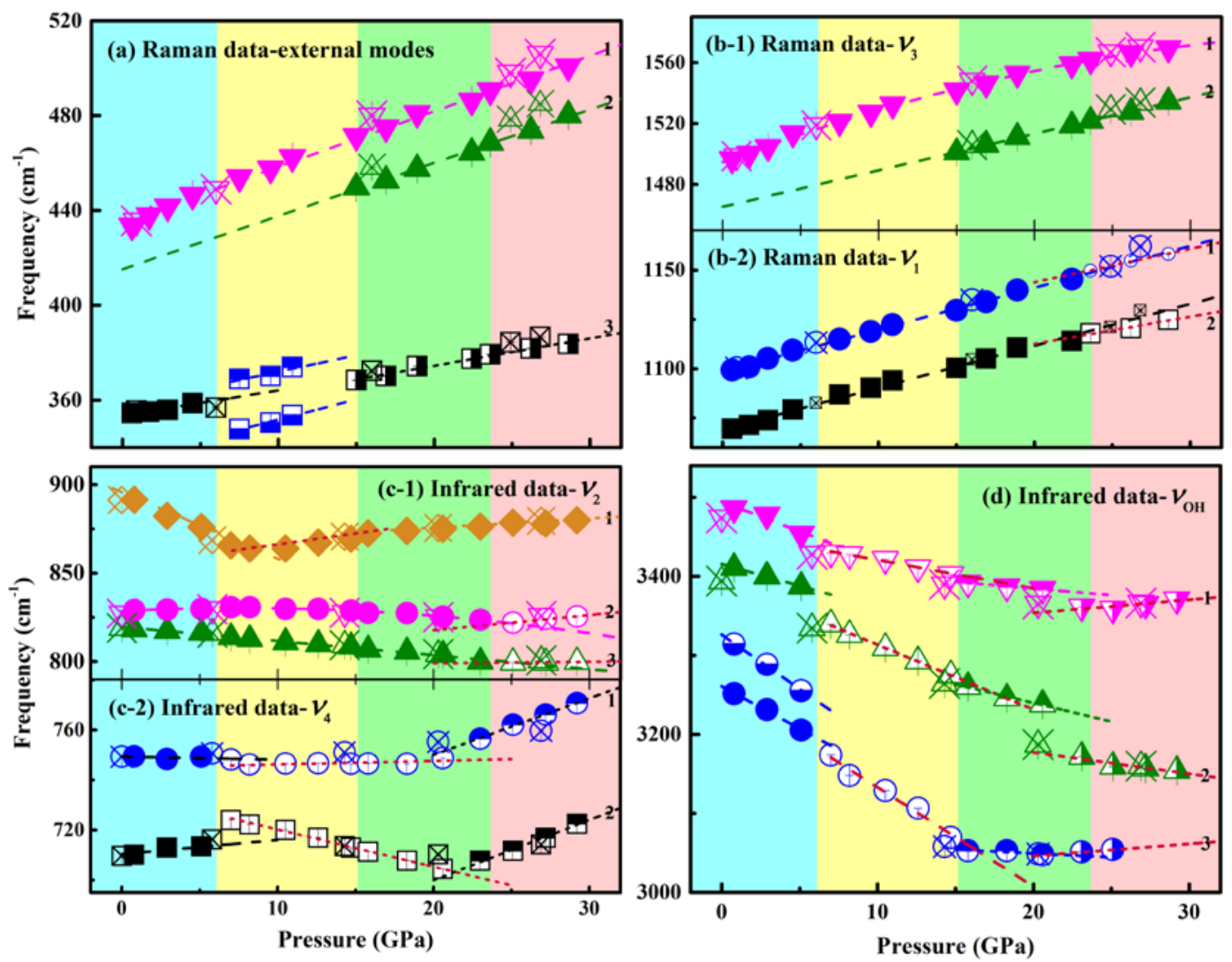

Figure 5. Pressure-dependences of (a) $\mathrm{Cu}-\mathrm{O}$ vibrations, $(\mathbf{b}, \mathbf{c})\left[\mathrm{CO}_{3}\right]^{2-}$ modes, and (d) $\mathrm{O}-\mathrm{H}$ stretches in $\mathrm{Cu}_{2}\left(\mathrm{CO}_{3}\right)(\mathrm{OH})_{2}$. The characters ((a): solid triangles, solid squares and half solid squares; (b) solid triangles, solid and open circles, and solid and open squares; (c) solid diamonds, solid and open triangles, solid, half solid and open circles, and solid, half solid and open squares; (d): solid, half solid and open triangles, and solid, half solid and open circles) are representative of experiment data collected upon compression except for the ones with a $\times$ center symbolizing the decompressing data. Four discrete pressure regions with color contrast represent different relations. Linear regression is used for most data analysis except for an $\mathrm{O}-\mathrm{C}-\mathrm{O}$ asymmetrical band $v_{3-1}$ in (b-1) and an out-of-bending band $v_{2-2}$ in (c-1), both fitted by parabolic curves. The pressure slopes $\left(d_{v i} / d_{P}\right)_{T}$ derived from the fitting analyses are listed in Table 3.

Table 3. Pressure-dependences of modes $\left(d_{v i} / d_{P}\right)_{T}\left(\mathrm{~cm}^{-1} \cdot \mathrm{GPa}^{-1}\right)$ of three types in $\mathrm{Cu}_{2}\left(\mathrm{CO}_{3}\right)(\mathrm{OH})_{2}$ in different pressure regions.

\begin{tabular}{cccccc}
\hline Assignments & Modes & $\mathbf{0 - 7 ~ G P a}$ & $\mathbf{7 - 1 5 ~ G P a}$ & $\mathbf{1 5 - 2 3 ~ G P a}$ & $>$ 23 GPa \\
\hline \multirow{2}{*}{$\mathrm{Cu}-\mathrm{O}$} & $v_{\mathrm{Cu}-\mathrm{O} 1}$ & $2.34(3)$ & $2.34(3)$ & $2.34(3)$ & $2.34(3)$ \\
vibrations & $v_{\mathrm{Cu}-\mathrm{O} 2}$ & - & - & $2.24(5)$ & $2.24(5)$ \\
& $v_{\mathrm{Cu}-\mathrm{O} 3}$ & $1.06(3)$ & $1.38(5) / 1.69(4)$ & $1.15(6)$ & $1.15(6)$ \\
\hline & $v_{3-1}$ & $\sim 3.5$ & $\sim 2.9$ & $\sim 2.2$ & $\sim 1.6$ \\
& $v_{3-2}$ & - & - & $2.39(3)$ & $2.39(3)$ \\
& $v_{1-1}$ & $2.12(3)$ & $2.12(3)$ & $2.12(3)$ & $1.69(6)$ \\
O-C-O & $v_{1-2}$ & $2.12(4)$ & $2.12(4)$ & $2.12(4)$ & $1.38(8)$ \\
vibrations & $v_{2-1}$ & $-3.60(4)$ & $0.92(8)$ & $0.50(2)$ & $0.50(2)$ \\
& $v_{2-2}$ & $\sim 0.2$ & $\sim-0.2$ & $-0.60(1)$ & $0.85(4)$ \\
& $v_{2-3}$ & $-0.79(2)$ & $-0.79(2)$ & $-0.79(2)$ & $0.08(1)$ \\
& $v_{4-1}$ & $-0.12(7)$ & $0.13(2)$ & $0.13(2)$ & $2.25(7)$ \\
& $v_{4-2}$ & $0.56(8)$ & $-1.48(4)$ & $-1.48(4)$ & $2.40(5)$ \\
\hline \multirow{3}{*}{$\mathrm{O}-\mathrm{H}$ stretches } & $v_{\mathrm{OH}-1}$ & $-7.52(9)$ & $-3.51(3)$ & $-1.58(1)$ & $1.61(4)$ \\
& $v_{\mathrm{OH}-2}$ & $-5.54(1)$ & $-8.13(2)$ & $-4.71(4)$ & $-2.78(6)$ \\
& $v_{\mathrm{OH}-3}$ & $-10.72(6)$ & $-12.58(4)$ & $-1.03(2)$ & $1.54(1)$ \\
\hline
\end{tabular}




\section{Discussion}

\subsection{Structural Transitions of Malachite under Pressure}

We observed three phase transitions of malachite at pressures of $\sim 7, \sim 15$, and $\sim 23 \mathrm{GPa}$, respectively. A progressive degree of $\left[\mathrm{CuO}_{6}\right]$ deformation can be identified by the various pressure dependencies of the $\mathrm{Cu}-\mathrm{O}$ modes. In light of the transition of malachite described in previous studies $[20,21]$, the present results provide vibrational evidence for the notion that the pressurized deformation of the $\left[\mathrm{CuO} \mathrm{O}_{6}\right]$ octahedron is responsible for the rotation of the cell unit, resulting in a different orientation of the crystal cell in the higher-pressure phase.

A further increase in pressure (above $15 \mathrm{GPa}$ ) leads to the appearance of more modes, which implies that at least the number of formula units in the unit cell changed. Considering the vibrations of $\left[\mathrm{CO}_{3}\right]^{2-}$ in carbonates under high pressure conditions [30-34], we attribute the development of the $\left[\mathrm{CO}_{3}\right]^{2-}$ internal modes to a decreased symmetry of the local geometry. It is also noted that upon compression from $\sim 7$ to $\sim 23 \mathrm{GPa}$, the separation between the two O-C $-\mathrm{O}$ in-plane bands increases from $\sim 25$ to $\sim 50 \mathrm{~cm}^{-1}$. Likewise, the pressure-enhanced splitting of the asymmetrical stretches are also notable. The increased splitting originates from an increased asymmetry of the local geometry of $\left[\mathrm{CO}_{3}\right]^{2-}$ or more likely, the distortion of $\left[\mathrm{CO}_{3}\right]^{2-}$ itself [37]. One can expect a structural rearrangement gradually occurring in this pressure range, involving a tilt effect of the $\left[\mathrm{CO}_{3}\right]^{2-}$ units or a conversion from a $\left[\mathrm{CO}_{3}\right]^{2-}$ triangle to $\left[\mathrm{CO}_{4}\right]$ tetrahedron. We suggest that a possible trigger for this change should be that the approach of the triangle $\mathrm{O}^{2-}$ towards the central $\mathrm{C}^{4+}$ under pressure gets to its limit and the $\left[\mathrm{CO}_{3}\right]^{2-}$ approaches as non-planar. As a consequence, the overall compression mechanism of the structure changes. Above $23 \mathrm{GPa}$, the two principle $\mathrm{O}-\mathrm{C}-\mathrm{O}$ stretching bands slow down in their blueshift process, resulting in lower frequencies of the stretching modes under higher pressures in comparison with the values extrapolated from the lower-pressure data. Since the frequency of the symmetric stretch is predominantly determined by the $\mathrm{O}-\mathrm{C}-\mathrm{O}$ bond stretching force constant, it is a very sensitive probe of the $\mathrm{C}-\mathrm{O}$ bond strength [37]. The lowered frequencies of the stretches under higher pressures suggest that the $\mathrm{C}-\mathrm{O}$ bonds become a little bit weaker than those at lower pressures. Such a decreased bond strength may stem from a lengthening of the C-O bond, a shift in the effective charges of $\mathrm{C}^{4+} / \mathrm{O}^{2-}$ and/or a strengthening of the $\mathrm{Cu}-\mathrm{O}$ bonds [34]. Here we propose that the combination effect of an elongated $\mathrm{C}-\mathrm{O}$ bond and a reinforced $\mathrm{Cu}-\mathrm{O}$ bond is responsible for the weakening of the $\mathrm{C}-\mathrm{O}$ bonds. The idea that the $\mathrm{C}-\mathrm{O}$ bond grows longer under pressure has been reported in carbonates magnesite $\mathrm{MgCO}_{3}$ at $30 \mathrm{GPa}$, which is probably induced by a progressive rotation of the $\left[\mathrm{MgO}_{6}\right]$ octahedron $[38,39]$. Likewise, in malachite the lengthening of the $\mathrm{C}-\mathrm{O}$ bond may likely be the result of a continuous rotation of the $\left[\mathrm{CuO}_{6}\right]$ octahedron (as discussed above). Giving rise to the three phase transitions, a growth of pressure has a negligible effect on the intensity of most bands. This implies that the main character of the $\mathrm{C}-\mathrm{O}$ bonds remains unchanged. The rigidness of the $\left[\mathrm{CO}_{3}\right]^{2-}$ units to pressure is very common in $\left[\mathrm{CO}_{3}\right]^{2-}$-bearing minerals. For comparison, a series of $\left[\mathrm{SiO}_{4}\right]$-phases tend to amorphize under comparable pressure-temperature conditions $[40,41]$. Thus, the stability of $\left[\mathrm{CO}_{3}\right]^{2-}$ is superior from a crystal chemical standpoint. In addition, the observed phase transitions seem to not involve the broken $\mathrm{Cu}-\mathrm{O}, \mathrm{C}-\mathrm{O}$, or $\mathrm{H}-\mathrm{O}$ bonds as the transitions are readily reversible.

The chemistry of hydrogen bonding in malachite during compression is complex: it shows a mode disappearance $\left(3232.14 \mathrm{~cm}^{-1}, 0.8 \mathrm{GPa}\right)$ and mode emerging $\left(\sim 950 \mathrm{~cm}^{-1}\right)$ at $\sim 7 \mathrm{GPa}$, coupled with a decrease in the frequency of $\Delta v=\sim 48 \mathrm{~cm}^{-1}\left(3410.79 \mathrm{~cm}^{-1}, 0.8 \mathrm{GPa}\right)$ over 5.1-7 GPa pressure span. At $15 \mathrm{GPa}$ it exhibits a systematical mode hardening, and over the 20.6-23 GPa interval, there is a further decrease in the frequency of $\Delta v=\sim 66 \mathrm{~cm}^{-1}\left(3410.79 \mathrm{~cm}^{-1}\right)$. These changes hint at the presence of $\mathrm{O}-\mathrm{H}$ bonds in many types, with the evolution of each type of bond showing its own trend. The phenomenon that the $\mathrm{O}-\mathrm{H}$ modes generally shift to lower frequencies reflects an enhancement in the strength of the hydrogen bonding involving the shortening of the $\mathrm{O}-\mathrm{H}$ bond. The observation of a pressurized significant broadness in the band width indicates that the $\mathrm{O}-\mathrm{H} \cdots \mathrm{O}$ bonds may become 
more asymmetric [42] or there may be unresolved band splitting. According to the correlation function between $\mathrm{O}-\mathrm{H}$ stretching frequencies and $\mathrm{O} \cdots \mathrm{O}$ bond length [43], we calculated the distance of $\mathrm{O} \cdots \mathrm{O}$ as $2.72,2.80$, and $2.87 \AA$, respectively, for $3251.55,3410.79$, and $3485.88 \mathrm{~cm}^{-1}$ bands at $0.8 \mathrm{GPa}$. When pressure increased to $15.8 \mathrm{GPa}$, the $\mathrm{O}$... O length decreased successively as $2.66,2.73$, and $2.79 \AA$; but above $15.8 \mathrm{GPa}$, the $\mathrm{O} \cdots \mathrm{O}$ length corresponding to the $3251.55 \mathrm{~cm}^{-1}$ band remains almost unchanged, whereas the other two shorten to 2.69 and $2.77 \AA$ at $23.0 \mathrm{GPa}$, respectively. Above $\sim 23 \mathrm{GPa}$, a blueshift upon pressure is noted which, to the best of our knowledge, is not common in the case of $\mathrm{O}-\mathrm{H}$ stretches. It has been suggested that due to $\mathrm{H}-\mathrm{H}$ repulsion and $\mathrm{O}-\mathrm{H}$ bond elongation, the $\mathrm{O}-\mathrm{H}$ stretches will blueshift with pressure increasing [44-47]. In consideration of the sites and coordination mode of hydrogen in malachite, we propose that the blueshift of the $\mathrm{O}-\mathrm{H}$ stretches may possibly result from some re-organization of the hydrogen due to the compression of the coordinated $\left[\mathrm{CuO}_{6}\right]$ octahedron and a substantially increasing repulsion effect from $\mathrm{Cu}^{2+}$. Further, the $\mathrm{O} \cdots \mathrm{O}$ distance connected to the hydrogen shows no further shortening in the pressure range of 23.0-29.2 GPa. As the pressure dependence of the $\mathrm{O}-\mathrm{H}$ stretches changes at $\sim 23 \mathrm{GPa}$, matching closely the pressure at which the $\mathrm{O}-\mathrm{C}-\mathrm{O}$ bending starts to soften, we speculate that the evolution of the $\left[\mathrm{CO}_{3}\right]^{2-}$ units which connect with $\left[\mathrm{CuO}_{6}\right]$, exerts a significant impact on the anisotropic compression of the $\left[\mathrm{CuO}_{6}\right]$ octahedron, and further on the local geometry of hydrogen. In the entire compression process, the main change in the $\mathrm{O}-\mathrm{H}$ spectra is the evolution of the complex contour, involving two mixed bands dominantly at 3410.79 and $3485.88 \mathrm{~cm}^{-1}$ in a somewhat blurred contour at $0.8 \mathrm{GPa}$, which varies to a more blurred contour involving three components over a frequency span of 3000-3400 $\mathrm{cm}^{-1}$ prominently at $3391.76 \mathrm{~cm}^{-1}$ above $\sim 15 \mathrm{GPa}$, grows in amplitude at $3051.26 \mathrm{~cm}^{-1}$ above $\sim 23 \mathrm{GPa}$, and preserves this shape until $\sim 29 \mathrm{GPa}$. This evolution confirms a gradual reorientation or reordering of hydrogen under pressure. In spite of a little blueshift of several modes (including $\mathrm{Cu}-\mathrm{O}, \mathrm{O}-\mathrm{C}-\mathrm{O}$, and $\mathrm{O}-\mathrm{H}$ ), no considerable redshift was noted for the majority of the vibrations. This eliminates the possibility of an overhydrated state of malachite at the present experiment's conditions, but malachite has an easily pressurized deformable structure with rather large interspaces between the adjacent $\left[\mathrm{CuO}_{6}\right]$ layers, which is anticipated to be capable of accommodating additional amounts of water. This hypothesis calls for further verification by high-pressure and temperature experiments using a water medium.

\subsection{Expectations on Hydroxycarbonates in the Earth's Mantle}

At the molecular level, the site and stability of hydrogen in hydroxycarbonates are dependent on bond strength and local geometry; both are constrained directly by the coordinated polyhedron. In addition, the existence of the $\left[\mathrm{CO}_{3}\right]^{2-}$ units has an indirect, but important influence on the geometry of hydrogen. For example, in malachite the mode softening of $\mathrm{O}-\mathrm{C}-\mathrm{O}$ bending at $\sim 23 \mathrm{GPa}$ is related to the weakening of the strength of the hydrogen bonding. In fact, as the hydrogen bond acceptor, the strength of the $\mathrm{C}-\mathrm{O}$ bond is also greatly modified $[15,16]$. Their synergistic relations have already been documented by the experimental observation that the water and $\mathrm{CO}_{2}$ will be released simultaneously above $380^{\circ} \mathrm{C}$ at atmospheric pressure [18]. We speculate that some interrelations in the stability of water and carbon within hydroxycarbonate exist at high-pressure and temperature conditions. Our attempts to the high-pressure vibrations of malachite emphasize that the stability of the hydrogen bonding can be extended extensively by pressures up to $23 \mathrm{GPa}$. In this regard, we may expect an increased capacity in the water storage of malachite, associated with carbon storage, approaching, at most, the bottom of the Earth's transition zone. The stability of hydrogen in malachite may hold true for other hydroxycarbonates. In nature, more and more hydrogen-bearing and hydrous minerals (e.g., a phase Egg [48]; a water-bearing ringwoodite [13]; or ferropericlase [49]) have been discovered as inclusions in diamonds originated from the transition zone and the topmost of the lower mantle. These findings strongly support the view that not only is the mantle at least locally hydrated, but also the water recycling in the hydrous mantle associates closely with the carbon circulation.

The properties of water under mantle conditions have been the subject of petrologic and geophysical interest for decades. The water storage capacity of malachite, relative to dense hydrous magnesium 
silicates, following a relatively cold temperature path, is expected to be at analogous levels but with superior stabilities. The present spectroscopic data provide a manifestation and pressure range of the stability of hydrogen in malachite, which could have relevance for the high-pressure behaviors of other hydroxycarbonates $\left(M-\mathrm{CO}_{2}-\mathrm{H}_{2} \mathrm{O}\right.$ systems, $\mathrm{M}=\mathrm{Cu}, \mathrm{Zn}, \mathrm{Mg}$, etc.). The stability field of hydroxycarbonate should be further characterized by careful inspection using $\mathrm{X}$-ray diffraction and vibrational measurements at simultaneously high-pressure and temperature conditions.

\section{Conclusions}

The present study explored the high-pressure vibrations of a hydroxycarbonate, malachite $\mathrm{Cu}_{2}\left(\mathrm{CO}_{3}\right)(\mathrm{OH})_{2}$, by in-situ Raman and infrared spectroscopic measurements at room temperature up to 29 GPa. Substantial changes in the mode intensities and discontinuities disclose three phase transitions at pressures of $\sim 7, \sim 15$, and $\sim 23 \mathrm{GPa}$. Upon compression, the $\mathrm{Cu}-\mathrm{O}$ bands shift variously with pressure, suggesting an increasing degree of deformation of the $\left[\mathrm{CuO}_{6}\right]$ octahedron. The $\mathrm{O}-\mathrm{H}$ stretching modes redshift with considerable pressure slopes up to $\sim 15 \mathrm{GPa}$, above which a mode hardening occurs which reflects some reorientation or reordering of the hydrogen bonding or a transition of the hydrogen sites. These changes indicate the occurrence of a new phase which is characterized with additional modes pointing to a different number of formula units in the unit cell. At further increments in pressure above $\sim 23 \mathrm{GPa}$, the $\mathrm{O}-\mathrm{C}-\mathrm{O}$ in-plane modes soften and the $\mathrm{O}-\mathrm{H}$ stretches start to shift to higher frequencies. These anomalies imply a weakening of the hydrogen bonding due at least partly to the evolution of the $\left[\mathrm{CO}_{3}\right]^{2-}$ units. Our results thus suggest an increasing capacity of water storage of malachite up to $\sim 23 \mathrm{GPa}$. The evolution of hydrogen bonding in malachite varying with pressure may hold true for other analogous hydroxyl minerals. Moreover, we highlight that in hydroxycarbonates the stability of hydrogen seems to be associated with that of carbon.

Author Contributions: Conceptualization, methodology, formal analysis, resources, data curation, project administration, funding acquisition, supervision, writing — original draft: J.G.; investigation, software, validation, visualization, writing-review and editing: J.G. and X.Y. All authors have read and agreed to the published version of the manuscript.

Funding: This work was supported by the China Postdoctoral Science Foundation (Grant No. 2018M640179 and 2019T120132) and a grant fund for research from the State Key Laboratory of Lithospheric Evolution, Institute of Geology and Geophysics, Chinese Academy of Sciences, China.

Acknowledgments: We gratefully acknowledge the assistance from Xiaoming $\mathrm{Xu}$ for the sample composition analyses.

Conflicts of Interest: The authors declare no conflicts of interest.

\section{References}

1. Ardia, P.; Hirschmann, M.M.; Withers, A.C.; Tenner, T.J. $\mathrm{H}_{2} \mathrm{O}$ storage capacity of olivine at 5-8 GPa and consequences for dehydration partial melting of the upper mantle. Earth Planet Sci. Lett. 2012, 345, 104-116. [CrossRef]

2. Revenaugh, J.; Sipkin, S.A. Seismic evidence for silicate melt atop the 410-km mantle discontinuity. Nature 1994, 369, 474-476. [CrossRef]

3. Lawrence, J.F.; Wysession, M.E. Seismic evidence for subduction-transported water in the lower mantle. Earth's Deep Water Cycle. AGU 2013, 168, 251-261.

4. Frost, D.J. The stability of dense hydrous magnesium silicates in Earth's transition zone and lower mantle. Mantle Petrology: Field observations and high pressure experimentation: A tribute to francis R.(Joe) Boyd. Geochem. Soc. 1999, 6, 283-296.

5. Nishi, M.; Irifune, T.; Tsuchiya, J.; Tange, Y.; Nishihara, Y.; Fujino, K.; Higo, Y. Stability of hydrous silicate at high pressures and water transport to the deep lower mantle. Nat. Geosci. 2014, 7, 224-227. [CrossRef]

6. Ohtani, E.; Livasov, A.K.; Haosoya, T.; Kubo, T.; Kondo, T. Water transport into the deep mantle and formation of a hydrous transition zone. Phys. Earth Planet. Int. 2004, 143, 255-269. [CrossRef]

7. Ringwood, A.E.; Major, A. High-pressure reconnaissance investigations in the system $\mathrm{Mg}_{2} \mathrm{SiO}_{4}-\mathrm{MgO}-\mathrm{H}_{2} \mathrm{O}$. Earth Planet. Sci. Lett. 1967, 2, 130-133. [CrossRef] 
8. Ghosh, S.; Schmidt, M.W. Melting of phase D in the lower mantle and implications for recycling and storage of $\mathrm{H}_{2} \mathrm{O}$ in the deep mantle. Geochim. Cosmochim. Acta 2014, 145, 72-88. [CrossRef]

9. Ohtani, E.; Litasov, K.; Suzuki, A.; Kondo, T. Stability field of new hydrous phase, $\delta$-AlOOH, with implications for water transport into the deep mantle. Geophys. Res. Lett. 2001, 28, 3991-3993. [CrossRef]

10. Ohira, I.; Ohtani, E.; Sakai, T.; Miyahara, M.; Hirao, N.; Ohishi, Y.; Nishijima, M. Stability of a hydrous $\delta$-phase, $\mathrm{AlOOH}-\mathrm{MgSiO}_{2}(\mathrm{OH})_{2}$, and a mechanism for water transport into the base of lower mantle. Earth Planet. Sci. Lett. 2014, 401, 12-17. [CrossRef]

11. Huang, X.G.; Xu, Y.S.; Karato, S.I. Water content in the transition zone from electrical conductivity of wadsleyite and ringwoodite. Nature 2005, 434, 746-749. [CrossRef] [PubMed]

12. Karato, S. Water distribution across the mantle transition zone and its implications for global material circulation. Earth Planet. Sci. Lett. 2011, 301, 413-423. [CrossRef]

13. Pearson, D.G.; Brenker, F.E.; Nestola, F.; McNeill, J.; Nasdala, L.; Hutchison, M.T.; Matveev, S.; Mather, K.; Silversmit, G.; Schmitz, S.; et al. Hydrous mantle transition zone indicated by ring-woodite included within diamond. Nature 2014, 507, 221-224. [CrossRef] [PubMed]

14. Williams, P.A. Oxide Zone Geochemistry; Ellis Horwood Ltd.: Chichester, UK, 1990.

15. Schmidt, M.; Lutz, H.D. Hydrogen bonding in basic copper salts: A spectroscopic study of malachite, $\mathrm{Cu}_{2}(\mathrm{OH})_{2} \mathrm{CO}_{3}$, and brochantite, $\mathrm{Cu}_{4}(\mathrm{OH})_{6} \mathrm{SO}_{4}$. Phys. Chem. Miner. 1993, 20, 27-32. [CrossRef]

16. Zigan, F.; Joswig, W.; Schuster, H.U.; Mason, S.A. Verfeinerung der Struktur von Malachit, $\mathrm{Cu}_{2}(\mathrm{OH})_{2} \mathrm{CO}_{3}$, durch Neutronenbeugung. Z. Kristallogr. 1977, 145, 412-426. [CrossRef]

17. Kiseleva, I.A.; Ogorodova, L.P.; Melchakova, L.V.; Bisengalieva, M.R.; Becturganov, N.S. Thermodynamic properties of copper carbonates-malachite $\mathrm{Cu}_{2}\left(\mathrm{CO}_{3}\right)(\mathrm{OH})_{2}$ and azurite $\mathrm{Cu}_{3}\left(\mathrm{CO}_{3}\right)_{2}(\mathrm{OH})_{2}$. Phys. Chem. Miner. 1992, 19, 322-333. [CrossRef]

18. Brown, I.W.M.; Mackenzie, K.J.D.; Gainsford, G.J. Thermal decomposition of the basic copper carbonates malachite and azurite. Thermochim. Acta 1984, 74, 23-32. [CrossRef]

19. Lee, Y.; Vogt, T.; Hriljac, J.A.; Parise, J.B.; Hanson, J.C.; Kimk, S.J. Non-framework cation migration and irreversible pressure-induced hydration in a zeolite. Nature 2002, 420, 485-489. [CrossRef]

20. Merlini, M.; Perchiazzi, N.; Hanfland, M.; Bossak, A. Phase transition at high pressure in $\mathrm{Cu}_{2} \mathrm{CO}_{3}(\mathrm{OH})_{2}$ related to the reduction of the Jahn-Teller effect. Acta Crystallogr. B 2012, 68, 266-274. [CrossRef]

21. Lebernegg, S.; Tsirlin, A.A.; Janson, O.; Rosner, $\mathrm{H}$. The spin gap in malachite $\mathrm{Cu}_{2}(\mathrm{OH})_{2} \mathrm{CO}_{3}$ and its evolution under pressure. Phys. Rev. B 2013, 256070369.

22. Mao, H.K.; Shen, G.; Hemley, G.J.; Duffy, T.S. X-ray diffraction with a double hot-plate laser-heated diamond cell. In Properties of the Earth and Planetary Materials at High Pressure and Temperature, American Geophysical Union; Manghnani, M.H., Yagi, T., Eds.; American Geophysical Union: Washington, DC, USA, 1998; pp. 27-34.

23. Mao, H.K.; Xu, J.A.; Bell, P.M. Calibration of the ruby pressure gauge to 800 kbar. J. Geophys. Res. 1986, 91, 4673-4676. [CrossRef]

24. Bouchard, M.; Smith, D.C. Catalogue of 45 reference Raman spectra of minerals concerning research in art history or archaeology, especially on corroded metals and coloured glass. Spectrochim. Acta A 2003, 59, 2247-2266. [CrossRef]

25. Frost, R.L.; Martens, W.N.; Rintoul, L.; Mahmutagic, E.; Kloprogge, J.T. Raman spectroscopic study of azurite and malachite at 298 and 77 K. J. Raman Spectrosc. 2002, 33, 252-259. [CrossRef]

26. Buzgar, N.; Apopei, A.I. The Raman study of certain carbonates. Analele Stiintifice Ale Universitatii AL I Cuza Iasi. Geologie 2009, 55, 97-112.

27. Yu, B.S.; Fang, J.N.; Huang, E.P. Characteristics of the Raman spectra of archaeological Malachites. J. Raman Spectrosc. 2013, 44, 630-636. [CrossRef]

28. Goldsmith, J.A.; Ross, S.D. The infra-red spectra of azurite and malachite. Spectrochim. Acta A 1968, 24, 2131-2137. [CrossRef]

29. Stoilova, D.; Koleva, V.; Vassileva, V. Infrared study of some synthetic phases of malachite $\left(\mathrm{Cu}_{2}(\mathrm{OH})_{2} \mathrm{CO}_{3}\right)$-hydrozincite $\left(\mathrm{Zn}_{5}(\mathrm{OH})_{6}\left(\mathrm{CO}_{3}\right)_{2}\right)$ series. Spectrochim. Acta A 2002, 58, 2051-2059. [CrossRef]

30. Efthimiopoulos, I.; Jahn, S.; Kuras, A.; Schade, U.; Koch-Müller, M. Combined high-pressure and high-temperature vibrational studies of dolomite: Phase diagram and evidence of a new distorted modification. Phys. Chem. Miner. 2017, 44, 465-476. [CrossRef]

31. Gao, J.; Wu, X.; Qin, S.; Li, Y.C. Pressure-induced phase transformations of $\mathrm{PbCO}_{3}$ by $x$-ray diffraction and Raman spectroscopy. High Pressure Res. 2016, 1, 1-15. [CrossRef] 
32. Gillet, P.; Biellmann, C.; Reynard, B.; McMillan, P. Raman spectroscopic studies of carbonates; part I, high-pressure and high-temperature behavior of calcite, magnesite, dolomite and aragonite. Phys. Chem. Miner. 1993, 20, 1-18. [CrossRef]

33. Kraft, S.; Knittle, E.; Williams, Q. Carbonate stability in the Earth's mantle: A vibrational spectroscopic study of aragonite and dolomite at high pressures and temperatures. J. Geophys. Res. 1991, 96, 17997-18009. [CrossRef]

34. Catalli, K.; Williams, Q. A high-pressure phase transition of calcite-III. Am. Mineral. 2005, 90, 437-444. [CrossRef]

35. Liu, Z.X.; Lager, G.A.; Hemley, R.J.; Ross, N.L. Synchrotron infrared spectroscopy of OH-chondrodite and $\mathrm{OH}$-clinohumite at high pressure. Am. Mineral. 2003, 88, 1412-1415. [CrossRef]

36. Mattei, E.; De Vivo, G.; De Santis, A.; Gaetani, C.; Pelosi, C.; Santamaria, U. Raman spectroscopic analysis of azurite blackening. J. Raman Spectrosc. 2008, 39, 302-306. [CrossRef]

37. White, W.B. The carbonate minerals. In The Infrared Spectra of Minerals; Farmer, V.C., Ed.; Mineralogical Society Monograph: London, UK, 1974; pp. 227-279.

38. Fiquet, G.; Guyot, F.; Kunz, M.; Matas, J.; Andrault, D.; Hanfland, M. Structural refinements of magnesite at very high pressure. Am. Mineral. 2002, 87, 1261-1265. [CrossRef]

39. Santillan, J.; Catalli, K.; Williams, Q. An infrared study of carbon-oxygen bond distance in magnesite from 0 to 60 GPa. Am. Mineral. 2005, 90, 1669-1673. [CrossRef]

40. Williams, Q.; Jeanloz, R. Static amorphization of anorthite at $300 \mathrm{~K}$ and comparison with diaplectic glass. Nature 1989, 338, 413-415. [CrossRef]

41. Williams, Q.; Iratittle, E.; Reichtin, R.; Martin, S.; Jeanloz, R. Structural and electronic properties of $\mathrm{Fe}_{2} \mathrm{SiO}_{4}$-fayalite at ultra-high pressures: Amorphization and gapclosure. J. Geophys. Res. 1990, 95, 21549-21563. [CrossRef]

42. Rundle, R.E.; Parasol, M. O-H stretching frequencies in very short and possibly symmetrical hydrogen Bonds. J. Chem. Phys. 1952, 20, 1487-1488. [CrossRef]

43. Libowitzky, E. Correlation of $\mathrm{O}-\mathrm{H}$ stretching frequencies and $\mathrm{O}-\mathrm{H}-\mathrm{O}$ hydrogen bond lengths in minerals. Monatsh. Chem. 1999, 130, 1047-1059.

44. Hofmeister, A.M.; Cynn, H.; Burnley, P.C.; Meade, C. Vibrational spectra of dense, hydrous magnesium silicates at high pressure: Importance of the hydrogen bond angle. Am. Mineral. 1999, 84, 454-464. [CrossRef]

45. Kleppe, A.K.; Jephcoat, A.P.; Welch, M.D. The effect of pressure upon hydrogen bonding in chlorite: A Raman spectroscopic study of clinochlore to $26.5 \mathrm{GPa}$. Am. Mineral. 2003, 88, 567-573. [CrossRef]

46. Liu, L.G.; Lin, C.C.; Mernagh, T.P. Raman spectra of norbergite at various pressures and temperatures. Eur. J. Mineral. 1999, 11, 1011-1021. [CrossRef]

47. Lutz, H.D. Hydroxide ions in condensed materials-correlation of spectroscopic and structural data. Struct. Bond. 1995, 82, 86-103.

48. Wirth, R.; Vollmer, C.; Brenker, F.; Matsyuk, S.; Kaminsky, F. Nanocrystalline hydrous aluminium silicate in superdeep diamonds from Juina (Mato Grosso State, Brazil). Earth Planet. Sci. Lett. 2007, 259, 384-399. [CrossRef]

49. Palot, M.; Jacobsen, S.D.; Townsend, J.P.; Nestola, F.; Marquardt, K.; Miyajima, N.; Harris, J.W.; Stachel, T.; McCammon, C.A.; Pearson, D.G. Evidence for $\mathrm{H}_{2} \mathrm{O}$-bearing fluids in the lower mantle from diamond inclusion. Lithos 2016, 265, 237-3243. [CrossRef]

(C) 2020 by the authors. Licensee MDPI, Basel, Switzerland. This article is an open access article distributed under the terms and conditions of the Creative Commons Attribution (CC BY) license (http://creativecommons.org/licenses/by/4.0/). 